\title{
Rancang Bangun Aplikasi Editor Album Foto Digital 'Fotokita' berbasis Desktop
}

\author{
M. Arief Ridwan, Rizky Januar Akbar, dan R.V. Hari Ginardi \\ Jurusan Teknik Informatika, Fakultas Teknologi Informasi, Institut Teknologi Sepuluh Nopember (ITS) \\ Jl. Arief Rahman Hakim, Surabaya 60111 Indonesia \\ e-mail: rizky@if.its.ac.id, hari@if.its.ac.id, aridwan05@gmail.com
}

\begin{abstract}
Abstrak-Seiring dengan fenomena semakin maraknya aktivitas pengabadian momen, dibutuhkannya teknologi yang memadai untuk mendukung aktifitas tersebut. Beberapa solusi telah ditawarkan oleh percetakan atau studio foto untuk menawarkan jasa membuat album foto. Tetapi di Indonesia belum ada aplikasi album digital berbasis desktop yang dapat memudahkan pengguna secara langsung untuk membuat album fotonya sendiri. Pada makalah ini, permasalahan tersebut akan ditangani dengan membuat aplikasi berbasis desktop yang mengakomodasi kebutuhan pengguna dalam merancang album foto. Dalam pengembangan aplikasi akan mengimplementasi berbagai fitur untuk mendukung pengguna merancang album foto. Pengujian dilakukan dengan melakukan uji coba merancang sebuah album foto. Dari hasil pengujian, aplikasi yang dirancang dan diimplementasikan telah memenuhi semua kebutuhan fungsional.
\end{abstract}

Kata Kunci-Album Foto, Foto Digital, Fotokita

\section{PENDAHULUAN}

$\mathrm{P}$ ERKEMBANGAN teknologi di bidang digital sudah berkembang dengan sangat pesat, terutama dalam bidang fotografi. Dalam hal mencetak foto, yang dulu harus menggunakan film dan kemudian mencetaknya melalui proses yang rumit, sekarang bisa dilakukan dengan sangat mudah dengan memindahkan berkas yang ada di dalam kartu memori ke dalam komputer dan mencetaknya pun hanya membutuhkan sebuah mesin cetak (printer) dan kertas foto, dan foto-foto tersebut lalu diletakkan ke dalam album foto. Proses tersebut pada saat ini dapat dilakukan dengan menggunakan komputer melalui aplikasi.

Seiring dengan fenomena semakin maraknya pengabadian momen, dibutuhkannya teknologi yang memadai untuk mendukung kebutuhan. Beberapa percetakan atau studio foto sudah menyediakan layanan untuk melakukan pengeditan foto dan album, tetapi terkadang hasil yang ada tidak sesuai dengan harapan klien dan memakan biaya lebih. Solusi untuk klien yang menginginkan untuk mencetak foto album sesuai dengan selera masing-masing sudah tersedia, tetapi untuk di Indonesia sendiri sarana yang tersedia masih berupa pengeditan album foto secara online, sedangkan kecepatan jaringan belum bisa dikatakan mampu untuk melakukan semua kegiatan secara online.

Aplikasi album foto digital berbasis desktop diperlukan untuk memudahkan pengerjaan tersebut. Selain itu, untuk dapat menarik perhatian pengguna, sebuah aplikasi harus mengikuti perkembangan zaman dan mode, dan dikarenakan adanya ketidakpastian perkembangan fitur, misalnya penambahan frame, layout, efek dan tema sesuai dengan kebutuhan dan selera pengguna, maka dibutuhkan aplikasi album foto digital yang modular, dimana nantinya modul-modul dalam album foto digital dapat diperbaharui, dihapus, atau diganti dengan mudah.

Tujuan dikembangkannya aplikasi ini adalah untuk memberikan solusi kemudahan perancangan album foto digital bagi pengguna.

\section{TINJAUAN PUSTAKA}

\section{A. Album Foto Digital}

Album foto digital adalah sekumpulan foto yang dibukukan dalam suatu wadah. Album foto digital yang digital adalah aplikasi perangkat lunak dimana pengguna dapat memindahkan berkas foto dari hardisk ke dalam basis data utama aplikasi tersebut. Perangkat lunak album foto digital biasanya memungkinkan pengguna untuk melihat, mengubah, dan mengatur foto dengan menggunakan antarmuka buku seperti yang menyerupai album foto tradisional.

Pada saat ini di Indonesia sudah terdapat beberapa usaha yang bergerak dalam bidang album foto digital seperti Photobook Indonesia ${ }^{1}$ Picbit Photobook $^{2}$ dan SnappyPhotobook ${ }^{3}$ tetapi masih terdapat beberapa kekurangan, yaitu:

- Editor berbasis web sehingga membutuhkan koneksi internet untuk mengedit album foto.

- Waktu untuk memuat halaman editor relatif lama sehingga tidak memungkinkan untuk mengedit foto dengan koneksi internet yang lambat.

\section{B. Image Processing}

Pengolahan citra atau image processing adalah salah satu cabang ilmu informatika yang mempelajari transformasi suatu citra menjadi citra yang lain melalu teknik dan algoritma pengolahan citra tertentu [1].

Jenis image processing yang digunakan dalam aplikasi adalah peningkatan kualitas citra (image enhancement). Peningkatan kualitas citra yang disediakan ada tiga macam yaitu peningkatan kontras, peningkatan pencahayaan, dan peningkatan ketajaman. Pengolahan citra pada aplikasi fotokita menggunakan pustaka OpenCV [2].

\footnotetext{
${ }^{3}$ http://www.snapyphotobook.com/site/
}

\footnotetext{
${ }^{1}$ http://www.photobookindonesia.com/

${ }^{2}$ http://picbitphotobook.com/
} 


\section{ANALISIS DAN PERANCANGAN SISTEM}

\section{A. Deskripsi Umum}

Fotokita terdiri dari dua platform yaitu desktop dan website. Aplikasi berbasis desktop berfungsi sebagai editor foto album dan website berfungsi untuk menangani proses bisnis yang terjadi antara pelanggan dan percetakan dalam proses pencetakan album foto.

Fotokita desktop merupakan aplikasi editor untuk merancang album foto bagi pengguna. Pengguna dapat melakukan pembuatan rancangan album foto digital dari awal hingga menjadi sebuah album foto digital. Fitur-fitur dasar yang diimplementasi adalah penambahan gambar, penambahan teks, pengubahan posisi gambar, pengubahan ukuran gambar dan peningkatan kualitas citra.

Kasus penggunaan pada aplikasi ini terdiri dari 16 kasus penggunaan yang dapat dilihat pada Gambar 1.

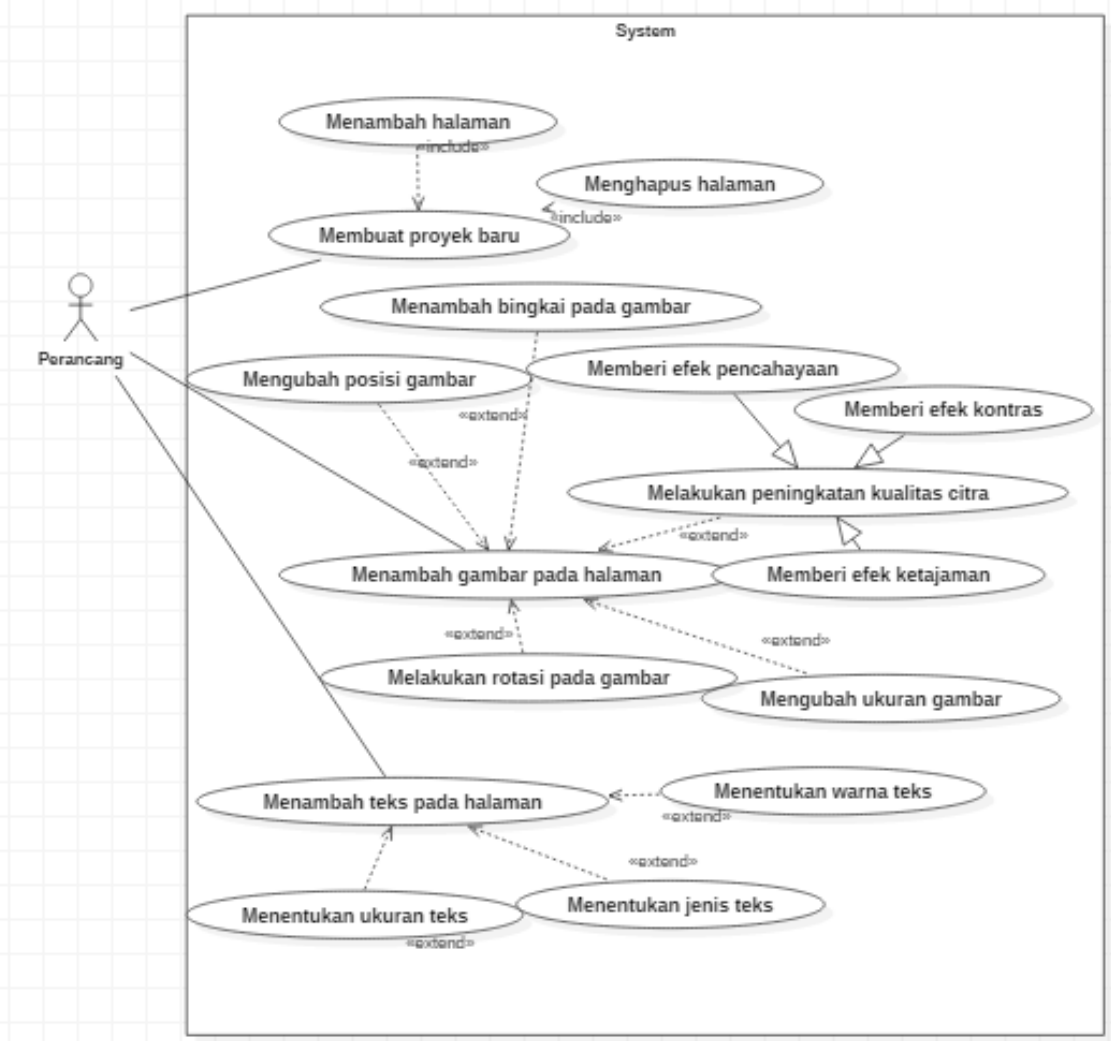

Gambar 1. Diagram kasus penggunaan.

\section{B. Perancangan Interface Fotokita}

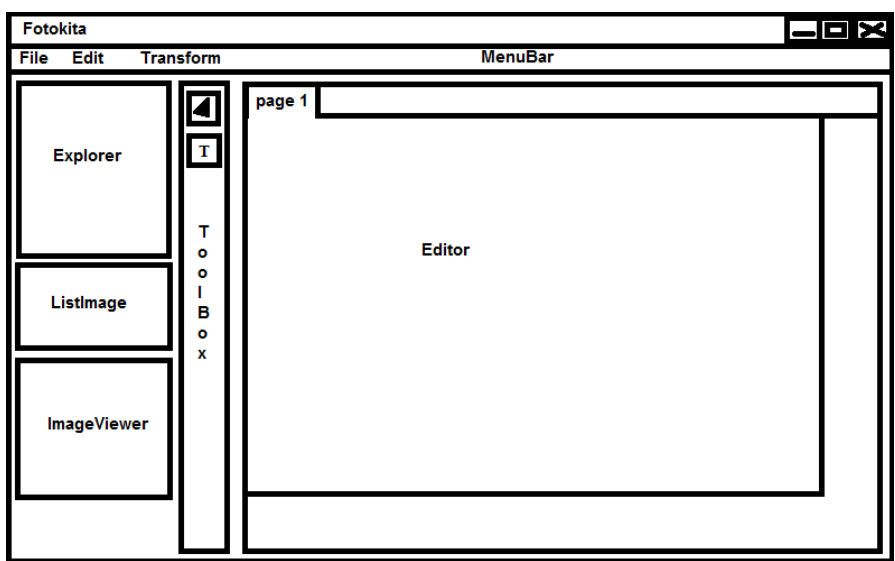

Gambar 2. Rancangan antarmuka album foto digital fotokita

Album Foto Digital Fotokita dapat dibagi menjadi beberapa bagian yaitu menubar, toolbar, toolbox, photo explorer, project explorer dan obyek yang bisa diletakkan pada page. Setiap bagian dapat dipecah menjadi bagian-bagian kecil lagi. Menubar memiliki menu dan menu items, toolbox terdiri dari tools, obyek yang bisa diletakkan pada page adalah frame, layout dan foto. Masing-masing bagian beserta pecahannya 
dibuatkan interface.

\section{Perancangan Diagram Kelas}

Struktur diagram kelas pada Fotokita ditunjukkan pada Gambar 3. Diagram kelas tersebut merupakan representasi dari objek apa yang dapat diinstansiasi. Kelas yang terdapat pada bagian paling bawah diagram merupakan kelas konkrit yang dapat diinstansiasi sedangkan kelas lainnya merupakan kelas abstrak.

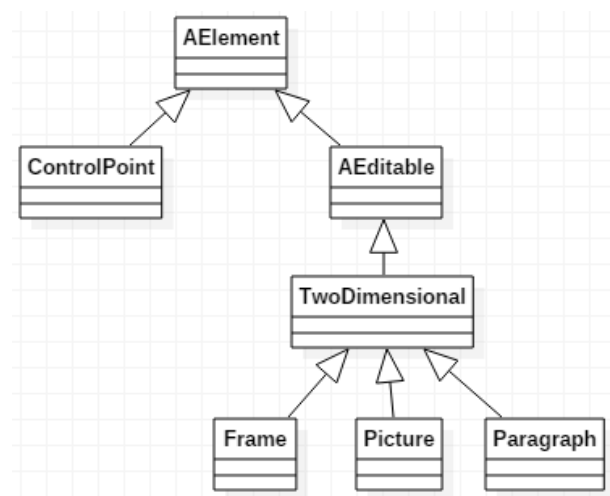

Gambar 3. Diagram kelas elemen fotokita

Ketika pengguna menambahkan gambar pada halaman, maka pengguna juga menginstansiasi kelas Picture, kelas Paragraph untuk teks, serta kelas Frame untuk bingkai.

Aplikasi Fotokita menerapkan pola perancangan untuk mempermudah pengembangan. Pola perancangan yang digunakan dalam aplikasi ada 3 macam yaitu singleton, observer pattern, dan state pattern.

Singleton adalah sebuah pattern yang membatasi penggunakan class menjadi sebuah instance saja pada sebuah aplikasi. Biasanya ada sebuah class pada aplikasi yang pada desain hanya dibutuhkan sekali. Salah satu diagram kelas singleton yang ada pada aplikasi dapat dilihat pada Gambar 4.

\begin{tabular}{|l|}
\hline \multicolumn{1}{|c|}{ MainWindow } \\
\hline -mainWindow: MainWindow \\
\hline +getInstance() \\
-MainWinwow() \\
\hline
\end{tabular}

Gambar 4 Diagram kelas singleton main window

Pola perancangan observer pattern adalah pola perancangan dimana sebuah objek mendaftarkan diri pada objek lain sehingga objek terdaftar dapat diketahui kondisinya. Pada pola ini ada dua buah status dari masing-masing objek yang berperan yaitu observer dan observable. Diagram kelas observer pattern dapat dilihat pada Gambar 5.

\begin{tabular}{|c|c|}
\hline Frame & Picture \\
\hline -observers: ArrayList<|Element $>$ & \multirow{2}{*}{+ notify ()} \\
\hline +notifyAllObserver() & \\
\hline+ drag 0 & \\
\hline
\end{tabular}

Gambar 5 Diagram kelas observer pattern frame dan picture

Fungsi notifyAllObserver pada kelas Frame akan dipanggil saat menjalankan fungsi drag. Sedangkan fungsi
notifyAllObserver adalah menjalankan fungsi notify pada IElement tersebut tergantung dari elemen apakah yang terdaftar pada Frame.

Pola perancangan state pattern akan diimplementasi pada kelas NormalState dan SizingState. Penggunaan kelas-kelas tersebut digunakan pada tiap state. Tiap kelas state memiliki fungsi draw yang berbeda. Diagram kelas state pattern dapat dilihat pada Gambar 6.

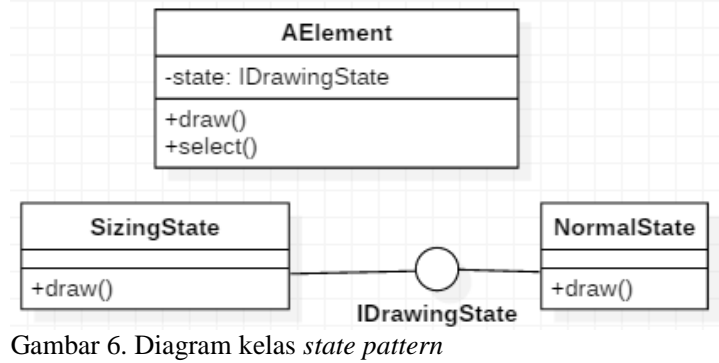

\section{IMPLEMENTASI}

\section{A. Lingkungan Implementasi}

Dalam merancang perangkat lunak ini digunakan beberapa perangkat pendukung yang terdiri dari perangkat keras dan perangkat lunak.

Spesifikasi perangkat keras yang digunakan dalam membangun web layanan transaksi photobook adalah sebagai berikut:

Tipe : Asus A455L

Prosesor $\quad$ : Intel $®$ Core TM $\mathrm{i5}-5200 \mathrm{CPU} @ 2.7 \mathrm{GHz}$ Memori : 4.00 GB RAM

Sistem Operasi : Windows 10 Enterprise 64 bit

Perangkat lunak yang digunakan dalam Fotokita berbasis desktop adalah sebagai berikut:

- Eclipse Mars digunakan sebagai IDE

- StarUML 2.7.0 digunakan untuk membuat digram kasus penggunaan, diagram aktivitas dan diagram kelas.

\section{B. Implementasi Fungsi Editor}

Fungsi yang akan diimplementasi pada fungsi editor ada 5 fungsi utama, fungsi tersebut antara lain:

1. Menambah gambar

2. Mengubah posisi gambar

3. Mengubah ukuran gambar

4. Merotasi gambar

5. Memanipulasi penambahan teks

Fungsi menambah gambar merupakan fungsi menginstansiasi kelas Picture dan menambahkannya ke dalam List yang digunakan untuk menampung tiap elemen terdaftar. Setelah elemen ditambahkan ke dalam List, tiap elemen akan digambar pada halaman.

Fungsi mengubah posisi gambar merupakan fungsi untuk mengubah nilai $x$ dan $y$ pada gambar. Fungsi ini terdapat pada kelas abstrak TwoDimensional yaitu fungsi $d r a g$.

Fungsi mengubah ukuran gambar terdapat pada kelas TwoDimensional pada fungsi drag. Fungsi tersebut membedakan saat pengguna memilih ControlPoint atau tidak. Saat pengguna memilih ControlPoint maka perlakuan akan berbeda saat pengguna melakukan drag and drop. 
Fungsi merotasi gambar berada pada kelas statis Rotator pada fungsi rotate. Fungsi ini merotasi ImageData yang dimiliki kelas Picture.

Mekasnisme penambahan teks merupakan mekanisme instansiasi dari kelas Paragraph. Saat pengguna menambahkan teks pada halaman pengguna mengatur semua atribut yang dibutuhkan untuk menginstansiasi kelas Paragraph.

\section{Implementasi Pengolahan Citra}

Pengolahan citra yang diimplementasi pada aplikasi menggunakan pustaka OpenCV versi 2.4.12. Seluruh kebutuhan untuk pengolahan citra telah disediakan dalam OpenCV.

Masing-masing jenis pengolahan citra memiliki algoritma yang berbeda-beda. Pengolahan citra yang disediakan adalah peningkatan kontras, peningkatan pencahayaan, dan peningkatan ketajaman citra.
Proses peningkatan kontras pada OpenCV menggunakan fungsi equalizeHist yang terdapat pada kelas Imgproc. Fungsi tersebut merupakan fungsi bawaan dari pustaka OpenCV untuk melakukan metode histogram equalization pada citra yang dipilih.

Proses peningkatan pencahayaan pada OpenCV menggunakan fungsi dari kelas Mat yaitu converTo. Fungsi tersebut digunakan dengan jenis kedalaman yang sama seperti Mat input, faktor skala 1, dan delta bernilai 31 .

\section{Implementasi Antarmuka}

Hasil implementasi dari perancangan antarmuka yang telah dibahas pada bagian sebelumnya akan ditampilkan pada bagian ini. Tampilan antarmuka utama Fotokita dapat dilihat pada Gambar 7. Sedangkan tampilan untuk peningkatan kualitas citra memiliki antarmuka yang berbeda dari antarmuka utama dapat dilihat pada Gambar 8.

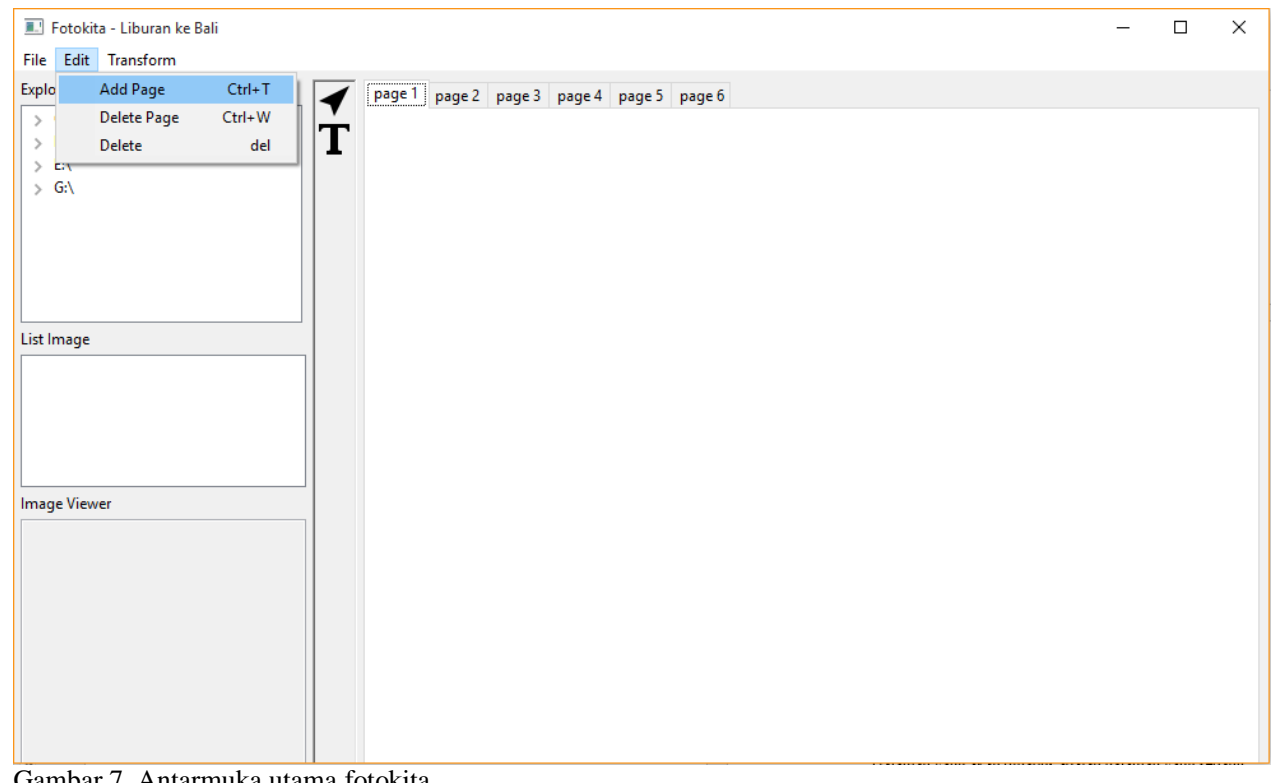

Gambar 7. Antarmuka utama fotokita

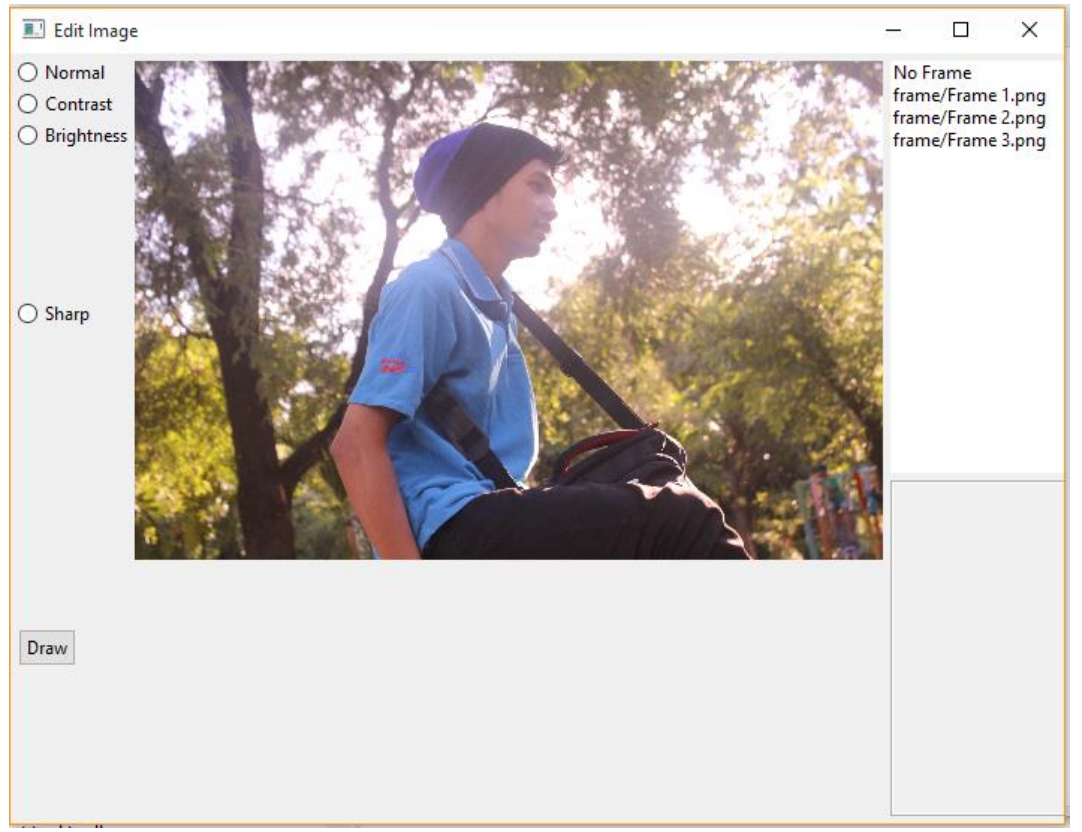

Gambar 8. Antarmuka utama peningkatan kualitas citra 


\section{PENGUJIAN DAN EVALUASI}

Pengujian yang dilakukan berupa pengujian fungsionalitas. Pengujian fungsionalitas dilakukan dengan model blackbox untuk menguji masing-masing kasus penggunaan.

Uji coba fungsionalitas administratif adalah uji coba yang dilakukan terhadap fungsionalitas yang dapat dilakukan oleh pengguna. Uji coba dilakukan dengan metode black box yang artinya fungsionalitas diperiksa apakah terpenuhi atau tidak tanpa melihat struktur internal ataupun metode yang digunakan dalam pengerjaan fungsionalitas tersebut.

Berdasarkan hasil pengujian fungsionalitas pada aplikasi Fotokita total ada 15 kasus pengujian aplikasi dan seluruh ujicoba berjalan dengan baik.

\section{KESIMPULAN}

Dari hasil pengamatan selama proses perancangan, implementasi dan pengujian perangkat lunak yang dilakukan, dapat diambil kesimpulan sebagai berikut:

1. Aplikasi dapat membantu pengguna merancang album foto berdasarkan fitur yang tersedia.

2. Gambar yang dipilih dapat ditingkatkan kualitasnya melalui peningkatan kualitas citra menggunakan fungsi bawaan pada pustaka OpenCV bergantung dengan jenis peningkatan kualitas yang diinginkan.

3. Aplikasi sudah memenuhi seluruh fitur yang tersedia dengan melakukan pengujian fungsionalitas pada tanggal 6 Juni 2016 di Laboratorium Dasar dan Terapan Komputasi.

\section{DAFTAR PUSTAKA}

[1] "tutorialspoint.com," [Online]. Available: http://www.tutorialspoint.com/dip/histogram_equalization.htm. [Accessed 2906 2016].

[2] OpenCV, "OpenCV.org," [Online]. Available: http://opencv.org/. [Accessed 2906 2016].

[3] M. Scarpiano, S. Holder, S. Ng and L. Mihalkovic, SWT/JFace in Action, Greenwich: Manning Publication, 2005. 